\title{
LAJOS TAKÁCS AND HIS WORK
}

\author{
JEWGENI H. DSHALALOW \\ Department of Applied Mathematics \\ Florida Institute of Technology \\ Melbourne, FL 32901, U.S.A. \\ RYSZARD SYSKI \\ Department of Mathematics \\ University of Maryland \\ College Park, MD 20742
}

(Received May, 1994; revised October, 1994)

\begin{abstract}
This paper, written in honor of the 70th birthday of Lajos Takács, addresses his life and work, and includes some personal observations and appreciation of his contributions. In particular, it includes a short biography, an informal discussion of some of his major research areas (queueing, fluctuations, waiting time processes, and random rooted trees), and an account of the relationship of his work to that of Félix Pollaczek.

Key words: Lajos Takács, fluctuations, queueing, semi-Markov processes, binomial moments, $M / G / 1, G I / G / 1$, multi-server queues, Banach algebras, Takács process, Lindley integral equation, random rooted trees, random graphs.
\end{abstract}

AMS (MOS) subject classifications: Primary: 01A70; Secondary: 60G50, 60G55, 60J15, 60K05, 60K15, 60K25, 90B22.

\section{Biographical Sketches of Lajos Takács}

\subsection{Introduction}

In the second half of 1994, many scientific institutions (including the Institute of Mathematical Statistics, Operations Research Society of America, The Institute of Management Sciences, and Hungarian Academy of Sciences) celebrated Lajos Takács' 70th birthday, which took place on August 21, 1994. In addition, a special volume, Studies in Applied Probability (31A of JAP, see reference [B], edited by J. Galambos and J. Gani), appeared in the first half of 1994 honoring Professor Takács. The authors of this paper were happy to participate in this honorable event by contributing a few essays on Lajos Takács life and work, which at least in part complement the fine articles by Bingham [2] and Takács [Tak, 183] himself. Here and throughout this paper, for convenience, we will distinguish the papers cited from the General References (by [xx]) and from Takács References (by [Tak, xx]), both placed at the end of this paper.

Because of his extraordinary accomplishments, Professor Takács is one of the most celebrated contemporary probabilists. He has published over 200 papers and books, many of which have had 
a huge impact on the contemporary theory of probability and stochastic processes. His numerous works are yet to be explored. Although some people view Takács as a queueing theorist, it is just one of many areas of his remarkable influence. This opinion about him is also because queueing theory (or, as they say, just queueing) has become so overwhelmingly popular, and because Takács is indisputably one of the greatest contributors to the theory who ever lived. This may outshine his other contributions to the theory of probability, stochastic processes, combinatorial analysis, and even physics. For instance, it is not widely known that Takács was the first to introduce and study semi-Markov processes in the early fifties (which appeared in one of his papers, see [Tak, 19] in 1954, and which he had been using even before 1954), perhaps one of the most extraordinary achievements in the theory of stochastic processes in the second half of the twentieth century. Later on, these processes were also introduced by Paul Lévy and Walter Smith, who reported about their discoveries at the International Congress of Mathematicians held in 1954 in Amsterdam, (see [13] and [24]) (although Lévy is most widely credited for this contribution).

In 1962 Takács published his Introduction to the Theory of Queues, a masterpiece and, at the same time, one of the most widely cited monographs in queueing. His other masterpiece, "On Fluctuations of Sums of Random Variables," published in 1978 [Tak, 157] is less popular, but it undoubtedly deserves more attention. Due to his phenomenal diversity, Takács left traces in many areas of mathematics and probability, such as: queueing theory, combinatorial analysis, point processes, random walks, branching processes, Markov processes, semi-Markov processes, probability on groups, signal processes, statistics, fluctuation theory, sojourn time problems in stochastic processes, ballot theorems, and random graphs. In spite of his numerous commitments, Takács is still amazingly productive. In 1993 he was elected a Foreign Member of the highly renowned Hungarian Academy of Sciences, and recently he was awarded the prestigious John von Neumann Theory Prize by the Operations Research Society of America and The Institute of Management Sciences. Currently, he is a professor emeritus at Case Western Reserve University in Cleveland, Ohio.

\subsection{Short Biography of Lajos Takács}

Lajos Takács was born on August 21, 1924, in Maglód, a small town near Budapest. At the age of 15, Lajos became interested in mathematics. His school teacher suggested that he read Euler's Algebra. During his Christmas vacation, not only did Lajos read this book, but also the Differential and Integral Calculus by Manó Beke. His teacher gave him a few problems from that book and Lajos impressed him by giving him the right answers. From now on, Lajos gets more and moré books in various topics of calculus from his teacher. Many of the books were written in German, and Lajos painstakingly translated them. Lajos' interests soon brought him to the library of the Technical University of Budapest. Throughout his high-school years he spent all his vacations and his free time studying mathematics. Besides calculus, he also taught himself linear algebra, analytic geometry, number theory, complex variables, differential equations, set theory and special functions, not counting physics, philosophy and literature. He initially found number theory most fascinating. His early interest in all fields of mathematics at least in part explains his unique mathematical versatility.

Lajos did not arrive at probability at once. Initially, his interests in probability were restricted to only combinatorics (one of the primary tools in solving various problems in probability). In fact, Lajos considered probability to be just a branch of combinatorics, not an independent discipline. Lajos' preference was deterministic mathematics as the result of his viewing the physical world as deterministic. The actual role of stochastics was recognized by him much later.

In the fall of 1943 Lajos enrolled at the Technical University of Budapest, then one of the 
finest European schools, where he studied mathematics and physics. Among various courses Lajos took at the Technical University, those of Professor Charles Jordan on probability theory and statistics were among the most memorable and decisive in choosing his career as a probabilist. Early in 1944 the war finally reached Hungary, followed by chaos and destruction, causing the suspension of classes, which resumed only late in 1945. Almost at the same time, young Lajos at the age of 21 accepted an offer by Dr. Zoltán Bay, a renowned professor of atomic physics, to become his student assistant and a research consultant in the prestigious Tungsram Research Laboratory, led by Professor Bay. Among the lab's employees, the majority of whom were faculty, Lajos was the only student. He participated in the development of various prominent projects, of which the experiment detecting microwave echoes from the moon was the most memorable. In February 1946 the moon experiment succeeded in placing the Tugsram Lab on a par with an American group of scientists conducting similar experiments. The results of the experiment were highly publicized, and Lajos' name always appeared along with other participants. As Lajos points out in his Chance or Determinism [Tak, 183], this has also been a triumph of stochastics, which was a part of the moon experiment based on separating the signal from the white noise.

In 1948, at the age of 24, Lajos obtained his doctorate with the thesis "On a ProbabilityTheoretical Investigation of Brownian Motion." Considering the traditionally high European educational standards, the rigor of the school, and the impact of the Second World War, it was quite an early age for the title which is equivalent to a Ph.D. in the United States and United Kingdom. There is, however, another degree beyond the Ph.D. level granted by most European schools and frequently called there by the German word Habilitation. It becomes almost imperative to get this title to preserve a higher academic position above Assistant Professorship. Lajos received his second (Habilitation) degree in 1957 for his thesis "Stochastic Processes Arising in the Theory of Particle Counters."

Until 1955, Lajos held a joint appointment at the Telecommunications Research Institute (formerly the Tungsram Research Laboratory) and at the Research Institute of Mathematics of the Hungarian Academy of Sciences. He conducted research in probability theory related to problems in physics. At the same time he wrote several papers on queueing involving applications to telephone traffic, inventories, dams, and insurance risk. He further developed the theory of point processes and introduced semi-Markov processes for the first time. The years 1954-1958 were especially productive. Lajos wrote and published 55 research papers [Tak, 14-68] on various topics in stochastic processes and the foundations of modern queueing theory. His research in queueing was summarized in one of his finest works, "Some Probability Questions in the Theory of Telephone Traffic," first published in Hungarian [Tak, 40] and later on translated into various languages [Tak, 71]. In this paper he developed a large variety of multichannel queueing systems, applying his extraordinary fluency in combinatorial and continuous mathematics. [One very special characteristic of virtually all Lajos' papers is their extraordinary readability and mathematical elegance. He has the unique ability to make his point clear without using measure-theoretical (heavy) machinery.] Lajos included in this paper primarily results for embedded queueing processes. Their extensions to continuous-time-parameter queueing processes were later on included in his celebrated monograph, Introduction to the Theory of Queues [Tak, 82], that appeared in 1962. This book also includes his studies on single-server and multiserver queueing systems, including models for telephone traffic and servicing of machines.

1958 was a turning point in Lajos' life. He received a visiting appointment at Imperial College of London and at the London School of Economics, where he lectured on the theory of stochastic processes and queueing. In 1959 Lajos accepted an offer from Columbia University in New York of an assistant professorship (his first job in the U.S.). In 1960 he was promoted to an associate professorship. He remained at Columbia until 1966. At Columbia Lajos taught probability theory, stochastic processes and queuing theory. During these years he had nine Ph.D. students: Lakshmi Venkataraman, Clifford Marshall, Ora Engelberg (Mrs. Percus), Joseph Gastwirth, 
Lloyd Rosenberg, Peter Linhart, Peter Welch, Saul Shapiro, and Paul Burke (who was already known for his seminal work on output processes). During his Columbia years he had a consulting job at Bell Laboratories and also at IBM. In the summer of 1961 he had a visiting position at Boeing, Seattle.

In the early sixties Lajos worked on the time-dependent behavior of various queuing processes, specifically waiting-time processes, one of which (according to the Encyclopedia of Statistical Sciences [Tak, 184]), the virtual waiting-time process, is now called the Takács process. He used analytic methods, complex variables, Laplace transforms, Rouché's theorem, Lagrange's expansion, an other techniques. Special topics included queues with feedback, queues with balking, queues with various orders of service, and priority queues. These topics were also relevant to his consulting work at Bell Telephone Laboratories. In 1960 he also started working on combinatorial methods in probability theory. He found a generalization of the classical ballot theorem of Bertrand which made it possible to solve many problems in queueing theory, in the theory of dams, and in order statistics.

In 1966 Lajos spent part of his sabbatical at Stanford University working on his other bestseller book, Combinatorial Methods in the Theory of Stochastic Processes [Tak, 118] which was published in 1967. Among other fine results, Lajos further explored the theory of fluctuations, one of the most important areas in the theory of probability and stochastic processes.

In 1966 Lajos was appointed professor of mathematics at Case Western Reserve University in Cleveland, Ohio, where he held his position until 1987, after which he became professor emeritus. At Case Western Lajos wrote over 100 monographs and research papers, and he had an additional 14 Ph.D. students: Nancy Geller, John Bushnell, Douglas Rowland, Roberto Altschul, Elizabeth Van Vought, Fabio Vincentini, Pauline Ramig, Jin Yuh Chang, Aliakhbar Montazer-Haghighi, Andreas Papanicolau, Sara Debanne, Josefina De los Reyes, Daniel Michael Cap, and Enio E. Velazco. His major research areas became sojourn time problems, fluctuation theory and random trees.

On April 9, 1959, Lajos Takács married Dalma Horváth. They have two daughters, Judith and Susan. Dalma is currently the chairman of the English Department at Notre Dame College, Ohio. Judith is a commercial artist and illustrator, and Susan is a legal assistant. In spite of their very intense professional activities, Lajos and Dalma enjoy reading, listening to classical music, and going to plays and operas.

\subsection{Personal Notes by Ryszard Syski}

The following remarks represent my own interpretation of events in which I participated.

One day in May 1957, when working in London, I received a paper with a letter from (then unknown to me) a Hungarian mathematician, Lajos Takács. A few days earlier I had received from Holland a paper on the same topic by Wim Cohen, whom I had already known since 1954. A natural thing for me to do was to introduce both authors to each other. This was indeed the classical situation of two persons working independently. And it was also the beginning of a beautiful friendship which survives to the present day.

Lajos and I met on 17 January 1958, soon after his arrival in London to lecture at Imperial College. I was working at that time on my book on Teletraffic, and our talks gave me an opportunity to include a description of his early papers. In August that year we both attended the International Congress of Mathematicians in Edinburgh. My wife and I remember seeing him trying to stop tears in his eyes when he looked at photos of the Hungarian Revolution and of Russian tanks invading Hungary. Lajos honored me by inviting me to be his best man at his wedding with Dalma (on 9 April 1959) and to "give him away." Indeed, he was alone in London and at that 
time no relative of his could leave Hungary to attend the wedding. I am not much of a speaker, but I tried to do my best; after all it was better than nothing. Soon after the wedding, Dalma and Lajos left for the US, where he accepted a position at Columbia University.

As the years passed by, we kept in contact. I visited Dalma and Lajos in Cleveland Heights on some occasions, and saw their happy family life. I also met his mother, who had managed to leave Hungary. I have always admired Lajos' scientific work, and it has been a pleasure to see his and Dalma's success.

Lajos has always recognized and appreciated Pollaczek's work, and expressed this fact on many occasions. Pollaczek, however, was always insistent on proper credit and any transgression, whether real or imaginary, displeased him and sometimes led to conflicts. In particular, he insisted that the famous formula for the mean waiting time in the most fundamental of all queueing systems, $M / G / 1$, should be called the "Pollaczek formula" rather than "PollaczekKhintchine"; he also claimed priority for the Pollaczek-Spitzer formula. Lajos was unlucky in this respect because he omitted Pollaczek's name in one of his early papers; not from malice, but from his sense of historical accuracy. It is a pity that these two pioneers in queueing theory differed on such a rather minor matter.

Let me add to this that Lajos and I have the same critical views on funding research in this country. As we indicated in our essays in [C], Lajos has been uncomfortable with the art of making extravagant promises, and he thought that any research support should be awarded for what a person has accomplished and not for what he or she promises to accomplish. Also, in my opinion, it is not right to measure success only by the amount of contract and grant money generated.

\section{Selected Topics in Lajos Takács' Research}

\subsection{Multi-Channel Queues}

Until the early forties, this very important area of queueing was explored only for the cases when the input stream of single customers was Poisson and service in each of the parallel channels was exponentially distributed. In 1943 Palm [12], then Pollaczek [15] in 1953 and Takács [Tak, 40], [Tak, 71], and [Tak, 82] studied a class of more general systems $G I / M / m / N$, in terms of David Kendall's accepted notation. Here GI stands for General Independent input stream of units (i.e. a renewal process), $M$ stands for Markov Process and in this case means that service in each of the channels is exponentially distributed, $m$ gives the number of servicing channels (which is finite or infinite), and $N$ denotes the capacity of the waiting room, which again can be finite or infinite. In the first case, we distinguish $N=0$ (a loss system) from $N>0$. The queueing processes in such systems are not Markovian, and the primary idea of Takács was to select random instants of time at which the transitions of the embedded process would form a Markov chain. The method of embedded Markov Chains was developed and used for the first time by David Kendall in his pioneering works [6-8].

Takács studied the information on the queueing process in the above systems at the epochs of customers' arrivals at the system. Let $A(x)$ denote the probability distribution function (p.d.f.) of interarrival times $\tau_{1}, \tau_{2}-\tau_{1}, \ldots,\left(\tau_{0}=0\right)$ of customers and let $\mu$ be the service rate in each of the channels. Introduce the following notations:

$$
\alpha(\theta)=\mathbf{E}\left[e^{-\theta \tau_{1}}\right], \alpha_{r}=\alpha(r \mu),
$$




$$
a_{s}=\left\{\begin{array}{cc}
\prod_{r=1}^{s} \frac{\alpha_{r}}{1-\alpha_{r}}, & s=1,2, \ldots \\
1, & s=0
\end{array}\right.
$$

and the operator

$$
R_{n}(f)=\left.\frac{1}{n !} \frac{d^{n}}{d z^{n}} f(z)\right|_{z=1}
$$

which gives the $n$th binomial moment if applied to a Taylor series $f$. Let $Q=\left\{Q_{n}\right\}$ be the queueing process valued at the moments $\tau_{0}-, \tau_{1}-, \ldots$, of customers arrivals, and let $\boldsymbol{P}=\left(p_{0}, p_{1}, \ldots\right)$ denote the steady state distribution of the embedded Markov chain $Q$ with the probability generating function (p.g.f.) $P(z)=\sum_{i \geq 0} p_{i} z^{i}$. As an example, we consider the "loss system" $G I / M / m / 0$ for which the p.g.f. satisfies the following equation:

$$
\begin{aligned}
& P(z)=\sum_{j=0}^{m} p_{j} \int_{0}^{\infty}\left(1-e^{-\mu x}+z e^{-\mu x}\right)^{j+1} A(d x) \\
& \quad+(1-z) P_{m} \int_{0}^{\infty} e^{-\mu x}\left(1-e^{-\mu x}+z e^{-\mu x}\right)^{m} A(d x) .
\end{aligned}
$$

Takács used a very elegant method of binomial moments to solve the above functional equation. First he applied the operator $R_{r}$ to (1) to obtain the system of equations

$$
B_{r}=\alpha_{r}\left(B_{r}+B_{r-1}\right)-\alpha_{r}\left(\begin{array}{c}
m \\
r-1
\end{array}\right) B_{m}, r=1, \ldots, m
$$

in binomial moments $B_{r}$. Then he represented $\alpha_{r}$ as the ratio $\frac{a_{r}}{a_{r-1}}$ to yield

$$
\frac{B_{r}}{a_{r}}=\frac{B_{r-1}}{a_{r-1}}-\frac{1}{a_{r-1}}\left(\begin{array}{c}
m \\
r-1
\end{array}\right) B_{m}
$$

(Here Takács showed his extraordinary proficiency in combinatorial analysis, acquired by him in his younger age and later on explored in his works [Tak, 27], [Tak, 60], [Tak, 110], [Tak, 116], [Tak, 164], [Tak, 172], and [Tak, 193].)

From (2) by summation one easily gets

$$
B_{n}=a_{n} B_{m} \sum_{r=n}^{m-1}\left(\begin{array}{c}
m \\
r
\end{array}\right) \frac{1}{a_{r}}, n=0,1, \ldots, m-1 .
$$

Since obviously $B_{0}=a_{0}=1$ we obtain

$$
B_{m}=\left\{\sum_{r=n}^{m-1}\left(\begin{array}{c}
m \\
r
\end{array}\right) \frac{1}{a_{r}}\right\}^{-1}
$$

and therefore have all binomial moments. The unknown probabilities can be restored from the formula

$$
p_{j}=\sum_{i=j}^{m}(-1)^{i-j}\left(\begin{array}{c}
i \\
j
\end{array}\right) B_{i}, j=0,1, \ldots, m .
$$

Specifically, $B_{m}=p_{m}$ is the "loss probability" or the likelihood that an arriving unit is going to be rejected.

\subsection{Remarks on Takács and Pollaczek}

Fluctuation theory has a long history and still is a very active field of research. Its prominence is due to contributions of many distinguished mathematicians. Applications to queueing 
theory began with the classical work of D. V. Lindley [14], 1952 and F. Spitzer [25], 1956.

Independent work was carried out by Félix Pollaczek, who used fluctuation theory as the first step in his analysis of queueing systems with $s \geq 1$ servers. His results are well known, but although they are often quoted by other researchers, only a few of them really read his papers. This is due perhaps to the fact that Pollaczek converted probabilistic description of a problem into analytic expressions, and framed his analysis in terms of integral equations with several complex variables (the evaluation of "disheartening integrals"). [It is remarkable how easily Pollaczek handled his complicated multidimensional complex integrals for $s \geq 1$.] Pollaczek summarized his results in two books [19] and [20] published in 1957 and in 1961; English summary appeared in [21]. For exposition and applications of Pollaczek's work, see books by P. Le Gall [11], J. W. Cohen [3] and J. H. A. de Smit [5]. Of great interest is the special issue of AEU Journal [A] honoring Pollaczek on the 100-th anniversary of his birth. In particular, it includes papers by J. W. Cohen [4], R. Syski [27], P. le Gall [12] and L. Takács [Tak, 205], and also a biography of Pollaczek written by F. Schreiber and P. Le Gall [10].

The paper [Tak, 205] of Takács mentioned above deserves special attention, as it combines his interest in abstract algebra with his contributions to fluctuation theory. This contribution has been already described in his earlier paper [Tak, 157]. See also an excellent survey of Takács' work in probability theory written by N. H. Bingham and published in the volume honoring Takács on his 70-th birthday [B]. Bingham [2] acknowledged very briefly Pollaczek's influence on Takács. It would be desirable to explore further those aspects of Takács' contributions which are related to Pollaczek.

Let us begin with a brief outline of Pollaczek's study of the waiting time-process in the queueing system $G I / G / 1$ with the FIFO service discipline. For a complete account see the references quoted above. Let $W_{n}$ be a random variable representing the waiting time of the $n$-th customer $(n=0,1,2, \ldots)$. In Pollaczek's notation the first customer carries number 0 . Denote by $Z_{n}$ a random variable representing the difference between the service time of the $n$-th and the interval time of the $(n+1)$-st customer. By assumption, the random the variables $Z_{n}$ are independent and identically distributed with a common characteristic function $\psi(s)$ satisfying regularity conditions, where $s$ is a complex number.

The following recurrence relation is well known:

$$
W_{n+1}=\max \left\{W_{n}+Z_{n}, 0\right\}, n=0,1, \ldots
$$

with $W_{0}$ assumed constant, in particular 0 . It is this relation which links queueing with fluctuation theory of partial sums. Indeed, the random variable $M_{n}$, defined by

$$
M_{n+1}=\max \left\{0, S_{0}, S_{1}, \ldots, S_{n}\right\}, n=0,1, \ldots
$$

where $S_{k}=Z_{0}+Z_{1}+\ldots+Z_{k}$, has the same distribution as the random variable $W_{n}$. Relation (3) was used by Pollaczek as the starting point of his derivation of what is now known as Pollaczek integral equation. Thus, following Pollaczek, write $\phi_{n}(s)$ for the characteristic function of $W_{n}$, and consider the generating function

$$
\Phi(s, z)=\sum_{n=0}^{\infty} \phi_{n}(s) z^{n}, \operatorname{Re}(s) \geq 0,|z|<1 .
$$

The crucial step involves the representation of $\phi_{n}(s)$ as a contour integral and obtaining a relation between $\phi_{n+1}(s)$ and $\phi_{n}(s)$ using recurrence relation (3). The summation over all $n$ yields the required integral equation for the generating function $\Phi(s, z)$. This equation is rather complicated, so for convenience it will be presented below in the form found by Takács.

It is a great achievement of Pollaczek's method that he found the solution of his equation in a 
closed simple form. He also obtained the equilibrium solution (when traffic intensity is less than 1), and showed that his theory encompasses results obtained by other researchers who used special methods. In particular, the Pollaczek-Spitzer identity and the Pollaczek-Khintchine formula are immediate corollaries. Pollaczek always stressed that his method is analytic in character, and not probabilistic.

Turn now to Takács. In his studies of fluctuation theory, Takács devoted several papers to the interpretation and extension of Pollaczek's work in this area. He summarized his results in [Tak, 205] which appeared in the AEU issue already mentioned. The following is a summary of that summary.

Takács considered the commutative Banach algebra $\mathbb{R}_{1}$ of functions $\Phi(s)$ defined, for $\operatorname{Re}(s)=0$, by the representation

$$
\Phi(s)=\mathbf{E}\left[\zeta e^{-s \eta}\right]
$$

where $\zeta$ and $\eta$ are complex and real random variables, respectively, and with norm

$$
\|\Phi\|=\mathbf{E}[|\mathbf{E}(\xi \mid \eta)|]
$$

Furthermore, he defined for $\operatorname{Re}(s) \geq 0$ and for $\operatorname{Re}(s) \leq 0$, respectively,

$$
\Phi^{+}(s)=\mathbf{E}\left[\zeta e^{-s \eta^{+}}\right], \Phi^{-}(s)=\mathbf{E}\left[\zeta\left(e^{-s \eta}-e^{-s \eta^{+}}\right)\right],
$$

where $\eta^{+}=\max (\eta, 0)$. Obviously,

$$
\Phi(s)=\Phi^{+}(s)+\Phi^{-}(s)
$$

for $\operatorname{Re}(s)=0$, and $\Phi^{+}(s) \in \mathbb{R}_{1}, \Phi^{-}(s) \in \mathbb{R}_{1}$. Takács showed the uniqueness of the above decomposition of $\Phi(s)$, and obtained an integral representation for $\Phi^{+}(s)$ and $\Phi^{-}(s)$. Next he introduced two bounded linear transformations (projections) $\mathbf{T}$ and $\mathbf{T}^{*}$ on $\mathbb{R}_{1}$ such that for $\Phi(s) \in \mathbb{R}_{1}$,

$$
\mathbf{T} \Phi(s)=\Phi^{+}(s) \text { for } \operatorname{Re}(s) \geq 0, \mathbf{T}^{*} \Phi(s)=\Phi^{-}(s)+\Phi^{+}(\infty) \text { for } \operatorname{Re}(s) \leq 0 .
$$

The above machinery suffices to elucidate Pollaczek's argument for the case of independent identically distributed random variables $\left(Z_{n}\right)$. Replacing $\eta$ by $W_{n}$ and taking $\zeta=1$, one obtains $\phi_{n}(s)$ in Pollaczek's notation. Hence, it follows from relation (3) that

$$
\phi_{n}(s)=\mathbf{T}\left[\phi_{n-1}(s) \psi(s)\right]
$$

for $n=1,2, \ldots$, and $R e(s) \geq 0$. Consequently, the generating function $\Phi(s, z)$ belongs to $\mathbb{R}_{1}$ and the Pollaczek integral equation can be written as

$$
\mathbf{T}\{\Phi(s, z)[1-z \psi(s)]\}=1,
$$

(for zero initial conditions). Its solution has the form

$$
\Phi(s, z)=\exp \{-\mathbf{T}(\log [1-z \psi(s)])\}
$$

for $\operatorname{Re}(s) \geq 0$ and $|z|<1$. The interesting feature of this approach is that it reduces the problem to neat algebraic operations. 
In order to extend Pollaczek's results, Takács considered a noncommutative Banach algebra $\mathbb{R}_{2}$ of matrix functions

$$
\Phi(s)=\left[\Phi_{i j}(s)\right]_{i, j \in \mathbf{I}}
$$

defined for $\operatorname{Re}(s)=0$, where $\Phi_{i j}(s) \in \mathbb{R}_{1}$ and $\mathbf{I}$ is a countable set; algebraic operations and the norm are defined appropriately. Transformations $\mathbf{T}$ and $\mathbf{T}^{*}$ are extended to $\mathbb{R}_{2}$ element by element. Then, for any $\Phi(s)$ in $\mathbb{R}_{2}$ with $|z|\|\Phi\|<1$, there exists a canonical factorization of the Wiener-Hopf type:

$$
1-z \Phi(s)=\Phi^{+}(s, z) \Phi^{-}(s, z)
$$

Consider now the semi-Markov process $\left(Z_{n}, X_{n}\right)$ where $\left(X_{n}\right)$ is a Markov chain with a state space I and a transition matrix $\left(p_{i j}\right)$. Denote

$$
\mathbf{P}\left\{Z_{n+1} \leq t, X_{n+1}=j \mid X_{n}=i\right\}=H_{i j}(t)
$$

and let $\Phi_{i j}(s)$ be the Laplace-Stieltjes transform of $H_{i j}(t)$. Obviously, $\Phi(s)$, defined as above, is in $\mathbb{R}_{2}$ and $\|\Phi\|=1$. Next write

$$
\phi_{i j}(s, n)=\mathbf{E}\left[e^{-s W_{n}} I_{\left\{X_{n}=j\right\}} \mid X_{0}=i\right]
$$

so,

$$
\phi_{n}(s)=\left[\phi_{i j}(s, n)\right]_{i, j \in I}, \text { for } \operatorname{Re}(s) \geq 0 .
$$

If $X_{0}$ and $\left(Z_{n}\right)$ are independent, then $\phi_{n}(s)$ is given formally by the same expressions as in the case considered above. With the same definition of the generating function $\Phi(s, z)$, one finds that $\Phi(s, z)$ satisfies an integral equation of the same form stated above (for zero initial conditions). Hence:

$$
\Phi(s, z)=\left[\Phi^{-}(0, z)\right]^{-1}\left[\Phi^{-}(s, z)\right]^{-1}
$$

for $\operatorname{Re}(s) \geq 0$ and $|z|<1$.

As already noted, the whole discussion can be carried out for arbitrary initial conditions. Takács as well as Pollaczek applied their methods to other problems besides the waiting time.

Remark. There are two points which deserve consideration when comparing approaches of these two authors. First, Pollaczek assumes that his transforms $\psi(s)$ etc. are regular at $s=0$. According to Takács, this assumption is unnecessary; it implies, for example, that all the moments exist. Second, Pollaczek does not prove the uniqueness of the solutions of his integral equations. Rigorous proofs would seem to be very difficult. The Banach algebra approach avoids all these difficulties. Takács' formulas are neat, easy to handle and allow some generalizations. Earlier, studies of Banach algebras of this type were rendered in works by Baxter [1], 1958, Kingman [10], 1966, and Rota [22], 1969.

Biographic Sketch. Félix Pollaczek (1892-1981), a mathematician, was born in Vienna, worked in Berlin (1922-1933), and after the Second World War settled in Paris, where he obtained French Citizenship in 1947. He was one of the early pioneers in Queueing Theory, and his impact on its development is of a lasting value. He is famous for being the first to obtain a solution for the waiting time processes in the multi-server system $G I / G / s$. His single server theory was ready around 1952 and its complete formulation appeared in book form in 1957, [19]; similarly, the general theory of multi-server systems was announced in 1953 and was later 
presented in book form in 1961, [20]. His approach, referred to as Pollaczek's Method, converted a probabilistic problem into an analytic problem, and in turn led to integral equations in several complex variables. Power of this method is augmented by the fact that answers to related questions for the same probabilistic situation (e. g. queue length) can often be obtained from equations of (almost) the same form, but with modified kernels. Pollaczek worked independently, and some of his results were later obtained by other scientists using simpler methods.

Pollaczek's work influenced also other fields, like fluctuation theory (maxima of partial sums of independent identically distributed random variables) and special functions (Pollaczek orthogonal polynomials). For a complete biography of Pollaczek, see reference [23]. For Takács' work in the theory of fluctuations see topic 9 in section 3 .

\subsection{Takács Process}

This process refers to the virtual waiting time process in a FIFO single-server queue of type $G I / G / 1$ and it is called by this name, cited and described in the Encyclopedia of Statistical Sciences [Tak, 184] in 1988. Note that the term "virtual time process" was originally called by Takács himself and studied in his pioneering work [Tak,22].

The Takács process is defined as follows. Let $\tau_{0}=0, \tau_{1}, \tau_{2}, \ldots$ be a renewal point process describing successive arrivals of single customers at a single-server queueing system. Suppose that the $n$th customer needs service time of length $s_{n}$ and that the random variables $s_{n}$ are independent and identically distributed according to p.d.f. $S$, and independent of the process $\tau=\left\{\tau_{n}\right\}$. The actual waiting time of the $n$th customer, $W_{n}$, equals the cumulative service times of all customers in the system ahead of the $n$th customer (including the one which is in service) at time $\tau_{n}$ and it is defined by recurrence relation (3) in the previous section. The Takács process, $\eta(t)$, is a continuous-time-parameter process that gives the time to process all customers present in the system at time $t$; it has positive increments $s_{n}$ at times $\tau_{n}, n=0,1, \ldots$, and at all other points (of time) it decreases linearly with slope -1 . Obviously, $W_{n}=\eta\left(\tau_{n}-\right)$. We will target the onedimensional distribution of the Takács process, $V(t, x)=\mathbf{P}\{\eta(t) \leq x\}$.

If the input to the system is Poisson (with parameter $\lambda$ ), i.e. $G I / G / 1$ reduces to an $M / G / 1$ model, then the Takács process is Markovian, and $V$ satisfies Kolmogorov's equation

$$
\left(\frac{\partial}{\partial t}-\frac{\partial}{\partial x}\right) V(t, x)=-\lambda[V(t, x)-S * V(t, \cdot)(x)]
$$

which frequently refers to the "Takács integro-differential equation. Here $*$ denotes the convolution operator (with respect to the second variable in $V$ ). Along with the initial condition

$$
V(0, x)=\mathbf{P}\{\eta(0) \leq x\}
$$

the boundary value problem (4-5) has a unique solution $V$ explicitly given in [Tak, 82], [Tak, 85], [Tak, 96], and [Tak, 118]. That solution, which depends on $t$ and $x$, is called in the theory of differential equations a transient solution as opposed to a so-called stationary solution, which refers to the behavior of the process when it reaches its equilibrium. Some processes may (for all practical purposes) reach the equilibrium or steady state rather quickly, some not. Consequently, the mathematical notion of the equilibrium is when time $t$ tends to infinity. The status of the process over a long period of time requires certain conditions normally expressed through the intensities of the input $(\lambda)$ and service $(s)$ processes for single-server queues, as

$$
\lambda<s .
$$

[Here $\lambda$ and $s$ are defined as the reciprocals of the mean inter-arrival and service times, respective- 
ly.]

In 1930, Pollaczek [16] and [17], and in 1932 Khintchine [9] independently obtained a simple formula for the stationary distribution

$$
W(x)=\lim _{n \rightarrow \infty} \mathbf{P}\left\{W_{n} \leq x\right\}
$$

of the actual waiting time process for $M / G / 1$ queue in terms of the Laplace-Stieltjes transform $\Omega(\theta)$ under condition $(6)$ :

$$
\Omega(\theta)=\frac{1-\lambda / s}{1-\lambda(1-\xi(\theta)) / \theta}, \operatorname{Re}(\theta) \geq 0
$$

This is the celebrated "Pollaczek-Khintchine" formula (where $\xi(\theta)=\mathbf{E}\left[e^{-\theta s_{1}}\right]$ ). Formula (7) is also called "Cramér's formula" in the theory of insurance risk. Here the $V(t, x)$ denotes the onedimensional distribution of a so-called "risk process," i.e. it gives the probability that in the time interval $(0, t]$ the total claim of all clients of an insurance company never exceeds the reserve of the company. It appears that the risk process is identical to the Takács process but refers to a totally different model. For this reason we will also denote the risk process by $\eta(t)$. In 1930 Cramér [see for instance, Tak, 142] showed that

$$
V(x)=\lim _{t \rightarrow \infty} \mathbf{P}\{\eta(t) \leq x\}
$$

exists and under condition (6) it's Laplace-Stieltjes transform satisfies the same formula (7) of Pollaczek-Khintchine. However (to the best of our knowledge), not before 1975, when Takács [Tak, 142] made a bridge between the two results and explained the nature of the coincidence, any connection between the formulas of Cramér and Pollaczek-Khintchine has been noticed.

Earlier, in 1955, Takács [Tak, 22] showed that

$$
W(x)=V(x)
$$

in relation to the queueing. For the general single-server systems, $G I / G / 1$, Takács showed that, given (6), the steady state distribution $V(x)$ of the Takács process exists and satisfies the integral equation

$$
V(x)=1-\frac{s}{\lambda}+\frac{s}{\lambda} W * \widetilde{S}(x),
$$

where $\widetilde{S}(x)=s \int_{0}^{x}[1-S(y)] d y$ and $W$ satisfies Lindley's integral equation [14].

The transient distribution $V(t, x)$ of the Takács process for $G I / G / 1$ was obtained by Takács in his widely cited works on fluctuations of partial sums of sequences of random variables (see, for instance, [Tak, 149] and [Tak, 157]) by solving operator recurrence equations (more general than those in $V(t, x))$.

\subsection{Random Rooted Trees}

The main results of Takács are concerned with various sets of rooted trees with $n$ vertices, and determine the asymptotic distributions of the total height and the width of a tree chosen at random in a given set.

A tree is a connected undirected graph which has no cycles, loops or multiple edges. The root of a tree is a vertex distinguished from the other vertices. The height of a vertex in a rooted tree 
is the distance from the vertex to the root, that is, the number of edges in the path from the vertex to the root. The total height of a rooted tree is the sum of the heights of its vertices. The width of a rooted tree is the maximal number of vertices at the same distance from the root.

To define various sets of rooted trees of interest, let us suppose that $R$ is a fixed set of nonnegative integers which contains 0 . Let $d$ be the greatest common divisor of all the integers belonging to $R$. Denote by $S_{n}(R)$ the set of rooted oriented (plane) trees with $n$ unlabeled vertices in which the degree of the root belongs to $R$ and if $j$ is the degree of any other vertex of the tree, then $j-1 \in R$. In a similar way denote by $S_{n}(R)$ the set of rooted trees with $n$ labeled vertices in which the degree of the root belongs to $R$ and if $j$ is the degree of any other vertex of the tree, then $j-1 \in R$. By using the ballot theorem, Takács proved that the number of trees in $S_{n}(R)$ is

$$
\left|S_{n}(R)\right|=\frac{1}{n} \text { Coeff. of } x^{n-1} \text { in }\left(\sum_{i \in R} x^{i}\right)^{n}
$$

and the number of trees in $S_{n}(R)$ is

$$
\left|S_{n}^{*}(R)\right|=(n-1) \text { ! Coeff. of } x^{n-1} \text { in }\left(\sum_{i \in R} \frac{x^{i}}{i !}\right)^{n} \text {. }
$$

The limit distribution functions can be expressed as the distribution functions of some functionals on the Brownian excursion process $\left\{\eta^{+}(t), 0 \leq t \leq 1\right\}$, namely

and

$$
\mathbf{P}\left\{\int_{0}^{1} \eta^{+}(t) d t \leq x\right\}=W(x)
$$

$$
\mathbf{P}\left\{\sup _{0 \leq t \leq 1} \eta^{+}(t) \leq x\right\}=F(x) .
$$

Two main results are as follows: Let us choose a tree at random in the set $S_{n}(R)$ assuming that each choice has the same probability. Denote by $\tau_{n}(R)$ the total height of the tree and $\delta_{n}(R)$ the width of the tree. If $n=m d+1(m=0,1, \ldots)$, then

and

$$
\lim _{n \rightarrow \infty} \mathbf{P}\left\{\frac{\sigma \tau_{n}(R)}{\sqrt{4 n^{3}}} \leq x\right\}=W(x)
$$

$$
\lim _{n \rightarrow \infty} \mathbf{P}\left\{\frac{\delta_{n}(R)}{\sigma \sqrt{n}} \leq x\right\}=F(x)
$$

where $\sigma$ is a positive real constant defined as

$$
\sigma^{2}=\left(\sum_{j \in R}\left(j^{2}-1\right) p^{j}\right) /\left(\sum_{j \in R} p^{j}\right)
$$

and $p$ is the only root of the equation

$$
\sum_{j \in R}(j-1) p^{j}=0
$$

in the interval $(0,1)$.

Let us choose a tree at random in the set $S_{n}^{*}(R)$ assuming that each choice has the same probability. Denote by $\tau_{n}^{*}(R)$ the total height of the tree and $\delta_{n}^{*}(R)$ the width of the tree. If $n=m d$ $+1(m=0,1, \ldots)$, then 


$$
\lim _{n \rightarrow \infty} \mathbf{P}\left\{\frac{\sigma^{*} \tau_{n}^{*}(R)}{\sqrt{4 n^{3}}} \leq x\right\}=W(x)
$$

and

$$
\lim _{n \rightarrow \infty} \mathbf{P}\left\{\frac{\delta_{n}^{*}(R)}{\sigma^{*} \sqrt{n}} \leq x\right\}=F(x),
$$

where $\sigma^{*}$ is a positive real constant defined as

$$
\left(\sigma^{*}\right)^{2}=\left(\sum_{j \in R}\left(j^{2}-1\right) \lambda^{j} / j !\right) /\left(\sum_{j \in R} \lambda^{j} / j !\right)
$$

and $\lambda$ is the only root of the equation

in the interval $(0, \infty)$.

$$
\sum_{j \in R}(j-1) \lambda^{j} / j !=0
$$

For references, see topic 12 in section 3 below.

\section{Major Topics in the Works of Lajos Takács}

Below we categorize all items in Takács References under the following topics. For convenience we drop the abbreviation "Tak" as his works only are cited in this section:

1. POINT PROCESSES. Time-dependent behavior of various point processes. Stationary processes. Bus paradox. Particle counters. Coincidence problems. Renewal processes. Telephone traffic processes. References: [3], [6-11], [16], [21], [32], [36], [38], [39], [40], [48], [49], [53], [74].

2. SECONDARY PROCESSES GENERATED BY POINT PROCESSES. Distribution and spectral decomposition. Particle counters. Shot noise. A generalization of Schottky's formula. References: [14], [15], [18], [28], [29], [30], [31], [45], [52].

3. QUEUEING PROCESSES. Time-dependent behavior of single- server and many-server queuing processes. Virtual waiting time. Queues with feedback. Semi-Markov queues. Queues with finite capacity. Theory of dams. Generalizations of Erlang's and Palm's formulas. Solution of a problem of Khintchine. References: [4], [5], [17], [22], [24], [37], [46-48], [55], [56], [61],[64], [66], $[67],[70],[71],[73],[75],[77-79],[81-88],[91-94],[96],[97],[99-101],[105],[109],[113],[117]$, [119], [120], [122], [128], [129], [133], [134], [140-144], [147], [149], [154], [155], [167], [184], [186], [188], [206], [211].

4. BINOMIAL MOMENTS. The problem of binomial moments. Existence and uniqueness.A generalization of Jordan's theorem. The method of binomial moments. References: [27], [60], [110], [116], [164], [172], [193].

5. SOJOURN TIME PROBLEMS. A new method for the solution of occupation time problems in the theory of stochastic processes. A generalization of the arc sine law of Paul Lévy. References: [44], [51], [54], [62], [63], [69], [105], [133], [139], [140], [169]

6. RANDOM WALKS. The ruin problem. The Bernoulli excursion. Random walks on groups and graphs. References: [50], [57], [159], [162], [166], [168], [171], [173], [178], [180], [181], [194], [195], [201]. 
7. BALLOT THEOREMS. Applications in queueing theory, order statistics, random graphs and elsewhere. References: [83], [89], [95], [100], [102], [103], [109], [124], [165], [174], [179].

8. ORDER STATISTICS. Distributions and limit distributions of various distribution-free statistics. References: [103], [104], [107], [111], [126], [131], [132], [146], [198], [201].

9. FLUCTUATION THEORY. Exact and limit distributions. A method of Banach algebras. References: [108], [112], [115], [125], [127], [136], [137], [145], [150-153], [157], [205].

10. COMBINATORIAL PROBLEMS. Problem of matching. Probléme des ménages. Eulerian numbers. Combinatorial identities. References: [24], [97-99], [118], [138], [158], [161], [163], [170], [172], [177], [182].

11. BRANCHING PROCESSES. Secondary electron emission. Critical branching processes. References: [1], [34], [90], [197].

12. RANDOM GRAPHS. Random trees. Distribution of the vertices by altitude. References: [185], [186], [188-192], [194], [196], [199], [200], [203], [204], [206], [207], [211].

Acknowledgement. The authors much appreciate Bob Cooper's extensive work in refereeing the paper and making numerous critical remarks and valuable suggestions. Also it was he who brought the two authors together.

\section{General References}

[A] Special Issue on Teletraffic Theory and Engineering in Memory of Félix Pollaczek, Archiv für Elektronik und Übertragungstechnik (AE ̈U), 47, No. 5/6, 1993.

[B] Galambos, J., Gani, J. (editors), Studies in Applied Probability, Papers in honour of Lajos Takács, JAP, special volume, 31A, 1994.

[C] Gani, J. (editor), The Craft of Probabilistic Modelling, A Collection of personal accounts, Springer Verlag, 1986.

[1] Baxter G., On operator identity, Pacific J. Math., 8 (1958), 649-663.

[2] Bingham, N. H., The work of Lajos Takács on Probability Theory, 29-39 in [B].

[3] Cohen, J. W., The single server queue, North Holland, 2nd edition, 1982.

[4] Cohen, J. W., Complex functions in Queueing Theory, 300-310 in [A].

[5] de Smith, J. H. A., Many server queueing systems, Thesis, Univ. of Technology, Delft, 1971.

[6] Kendall, D.G., On the generalized "birth-and-death" process, Ann. Math. Stat. 19 (1948), $1-15$.

[7] Kendall, D.G., Some problems in the theory of queues, Journ. Royal Stat. Soc. XIII, No. 2 (1951), 151-173.

[8] Kendall, D.G., Stochastic processes occurring in the theory of queues and their analysis by the method of the imbedded Markov chain, Ann. Math. Stat. 24 (1953), 338-354.

[9] Khintchine, A., Mathematisches über die Erwartung vor einem öffentlichen Schalter, Mat. Sbornik, 39 (1932), 73-84.

[10] Kingman, J.F.C., On the algebra of queues, Journ. Appl. Prob., 3, (1966), 285-326.

[11] Le Gall, P., Les systèmes avec ou sans attente et les processus stochastiques, Dunod, 1962.

[12] Le Gall, P., The application of Pollaczek's method to single server queueing networks, pages $326-329$, in $[\mathrm{A}]$.

[13] Lévy, P., Systèmes semi-markoviens à au plus une infinité dénombrable d'états possibles, Proceedings of the International Congress of Mathematicians, Amsterdam, 2, North- 
Holland, Amsterdam (1954), 294-295.

[14] Lindley, D.V., The theory of queues with a single server, Proc. Cambridge Phil. Soc., 48 (1952), 277-289.

[15] Palm, C., Intensitätsschwankungen im Fernsprechsverkehr, Ericsson Technics, 1, No. 44 (1943), 1-18S.

[16] Pollaczek, F., Über eine Aufgabe der Wahrscheinlichkeitstheorie, Teil I, Math. Z., 32 (1930), 64-100.

[17] Pollaczek, F., Über eine Aufgabe der Wahrscheinlichkeitstheorie, Teil II, Math. Z., 32 (1930), 729-750.

[18] Pollaczek, F., Généralisation de la théorie probabiliste des systémes téléphoniques sans dispositif d'attente, Compt. Rend. Acad. Sci. Paris, 236 (1953), 1469-1470.

[19] Pollaczek, F., Problèmes stochastiques posés par le phénomène de formation d'une queue d'attente à un guichet et par des phènomenes apparentés, Gauthier-Villars, 1957.

[20] Pollaczek, F., Théorie analytique relatifs á un groupe de lignes téléphoniques avec dospositif d'attente, Gauthier-Villars, 1961.

[21] Pollaczek, F., Concerning an analytic method for the treatment of queueing problems, in: Proc. Symposium on Congestion Theory, Smith, W. L., Willkinson, W. E. (editors), pages 1-42, Univ. North Carolina Press, 1965.

[22] Rota, G.-C., Baxter algebras and combinatorial identities. I-II, Bul. Amer. Math. Soc., 75 (1969), 325-364.

[23] Schreiber, F., Le Gall, P., In memoriam of Félix Pollaczek, (1892-1981), 275-281, in [A].

[24] Smith, W.L., Regenerative stochastic processes, Proceedings of the International Congress of Mathematicians, Amsterdam, 2, North-Holland, Amsterdam (1954), 304-305.

[25] Spitzer, F., A combinatorial lemma and its application to probability theory, Trans. Amer. Math. Soc., 82 (1956), 323-339.

[26] Syski, R., Markovian models, 109-125, in [C].

[27] Syski, R., Pollaczek's method in Queueing Theory, 282-299, in [A].

\section{Takács References}

[1] (with Faragó, P.S.), The probability distribution of the number of secondary electrons, Hungarica Acta Physica, 1, No. 6, (1949) 43-52.

[2] (with Dallos, A.), Az Elektroncsö, Tankönyvkiadó Nemzeti Vállalat, Budapest, 1950

[3] Gépegyüttállások valószinüségszámitási tágyalása, Magyar Technika, No. 10, (1950) 17-19.

[4] Több gép egyidejü müködésének valószinüségszámitási tágyalása, Magyar Technika, No. 11-12, (1950) 61-63.

[5] Gép együttállások valószinüségszámitási tágyalása tekintettel a várakozási idökre, Magyar Tud. Akadémia Mat. Term.-tud. Oszt. Közl. 1, (1951) 228-234.

[6] Bekövetkezési és koincidencia jelenségek tárgyalása idötartamban tetsszöleges eloszlásu történések esetén, Magyar Tud. Akadémia Mat. Fiz. Oszt. Közl. 1, (1951) 371-368.

[7] Occurrence and coincidence phenomena in case of happenings with arbitrary distribution law of duration, Acta Math. Acad. Sci. Hungaricae, 2, (1951) 275-298.

[8] Wahrscheinlichkeitstheoretische Behandlung von Koinzidenz-Erscheinungen, mit Ereignissen gleicher Zeitdauer. (Hungarian, German summary.) Comptes Rendus du Premier Congrés des Mathématiciens Hongrois, 27 août-2 septembre, 1950. Les Éditeurs de l'Académie, Budapest, 1952, 731-740.

[9] (with Rényi, A.), Sur les processus d'événements dérivés par un processus de Poisson et sur leurs applications techniques et physiques. (Hungarian. Russian and French summaries.), Magyar Tud. Akadémia Alk. Mat. Int. Közl. 1, (1952) 139-146.

[10] A new method for discussing recurrent stochastic processes. (Hungarian. Russian and English summaries.), Magyar Tud. Akadémia Alk. Mat. Int. Közl. 2, (1953) 135-151. 
[11] Coincidence problems arising in the theoy of counters. (Hungarian. Russian and English summaries.), Magyar Tud. Akadémia Alk. Mat. Int. Közl. 2, (1953) 153-163.

[12] (with Palásti, I., Rényi, A., and Szentmártony, T.), Ergänzung des Lagervorrates I. (Hungarian. Russian and German Summaries.), Magyar Tud. Akadémia Alk. Mat. Int. Közl. 2 (1953) 187-201.

[13] Valószinüségszámitás. Felsöoktatási Jegyzetellátó Vállalat, Budapest, 1953.

[14] Poisson-folyamat által származtatott másodlagos folyamatokról és azok fizikai alkalmazásairól, Magyar Tud. Akadémia Mat. Fiz. Oszt. Közl. 4, (1954) 473-504.

[15] On secondary processes generated by a Poisson process and their applications in physics, Acta Math. Acad. Sci. Hungaricae, 5, (1954) 203-236.

[16] Poisson-folyamat által származtatott történésfolyamatokról, Magyar Tud. Akadémia Mat. Fiz. Oszt. Közl. 4, (1954) 525-541.

[17] Várakozási idö-problémák tárgyalása Markov-folyamatok segitségével, Magyar Tud. Akadémia Mat. Fiz. Oszt. Közl. 4, (1954) 543-570.

[18] Bizonyos fizikai regisztráló berendezésekkel kapscolatos sztochasztikus folyamatokról, Magyar Tud. Akadémia Mat. Fiz. Oszt. Közl. 4, (1954) 571-587.

[19] Some investigations concerning recurrent stochastic processes of a certain type. (Hungarian. Russian and English summaries.), Magyar Tud. Akadémia Alk. Mat. Int. Közl. 3 (1954) 115-128.

[20] A Valószinüségszámitás Néhány Hiradástechnikai Alkalmazása. Mérnöki Továbbképzö Intézet, Budapest, 1954.

[21] On Processes of happenings generated by means of a Poisson process, Acta Math. Acad. Sci. Hungaricae, 6, (1955) 81-99.

[22] Investigation of waiting time problems by reduction to Markov processes, Acta Math. Acad. Sci. Hungaricae, 6, (1955) 101-129.

[23] On stochastic processes connected with certain physical recording apparatuses, Acta Math. Acad. Sci. Hungaricae, 6, (1955) 363-380.

[24] Megjegyzés Turán Pál "A kinai matematika történetének egy problémájáról” cimü dolgozatához. (Russian and English summaries.), Matematikai Lapok, 6, (1955) 27-29.

[25] (with Ziermann, M.), Valószinüségszámitás. Tankönyvkiadó, Budapest, 1955. Second edition, 1967. Third edition, 1972.

[26] Rekurrens folyamatok által szarmaztatott másodlagos sztochasztikus folyamatokról, Magyar Tud. Akadémia Mat. Fiz. Oszt. Közl. 5, (1955) 187-197.

[27] Az általános valöszinüségszámitási tételröl, Magyar Tud. Akadémia Mat. Fiz. Oszt. Közl. 5, (1955) 467-476.

[28] Elektroncsövek anódáram-ingadozásának valószinüsészámitási tárgyalása, A Távközlési Kutató Intézet Közleményei, 1, No. 2, (1955) 14-29.

[29] Anwendung wahrscheinlichkeitstheoretischer Methoden bei der Untersuchung gewisser meteoropathologischer Erscheinungen. (Hungarian. Russian and German summaries.), Magyar Tud. Akadémia Alk. Mat. Int. Közl. 3, (1955) 301-320.

[30] On secondary stochastic processes generated by recurrent processes, Acta Math. Acad. Sci. Hungaricae, 7, (1956) 17-29.

[31] Elektroncsövek anódáram-ingadozásának valószinüségszámitási tárgyalásáról, Magyar Tud. Akadémia Mat. Fiz. Oszt. Közl. 6, (1956) 27-51.

[32] On a probability problem arising in the theory of counters, Proc. Cambridge Phil. Soc. 52, (1956) 488-498.

[33] (with Orosz, G.), Über die Kodesysteme mit zufallsartig gewählten superponierten Koden, Dokumentation, 3, (1956) 9-22.

[34] Valószinüségszámitási módzser a szekunder elektronemisszió vizsgálatára, Magyar Tud. Akadémia Mat. Fiz. Oszt. Közl. 6, (1956) 199-211.

[35] On some probability problems in the theory of nuclear reactors. (Hungarian. Russian and English summaries.), Magyar Tud. Akadémia Mat. Kut. Int. Közl. 1, (1956) 55-66. 
[36] On some probability problems concerning the counting of particles. (Hungarian. Russian and English summaries.), Magyar Tud. Akadémia Mat. Kut. Int. Közl. 1, (1956) 93-98.

[37] On a probability problem arising in some traffic investigations. (Hungarian. Russian and English summaries.), Magyar Tud. Akadémia Mat. Kut. Int. Közl. 1, (1956) 99-107.

[38] On the sequence of events, selected by a counter from a recurrent process of events, Teoriya Veroyatn. i Primenen. 1 (1956) 90-102.

[39] On the sequence of events, selected by a counter from a recurrent process of events, Theor. Probability and Appl. 1, (1956) 81-91.

[40] Részecskeszámlálók elméletében fellépö sztocnasztikus folyamatokról, Magyar Tud. Akadémia Mat. Fiz. Oszt. Közl. 6, (1956) 369-421.

[41] On the generalization of Erlang's formula, Acta Math. Acad. Sci. Hungaricae, 7, (1956) 419-433.

[42] (with Orosz, G.), Some probability problems concerning the marking of codes into the superimposition field, Journ. of Documentation, 12, (1956) 231-234.

[43] (with Orosz, G.), Über gewisse mathematische Probleme der Dokumentationssysteme mit zufallsartig gewählten superponierten Koden. (Hungarian. Russian and German summaries.), Magyar Tud. Akadémia Mat. Kut. Int. Közl. 1, (1956) 357-378.

[44] On certain sojourn time problems in the theory of stochastic processes, Acta Math. Acad. Sci. Hungaricae, 8, (1957) 169-191.

[45] Über die wahrscheinlichkeitstheoretische Behandlung der Anodenstromschwankungen von Elektronenröhren, Acta Phys. Acad. Sci. Hungaricae, 7, (1957) 25-50.

[46] On a stochastic process concerning some waiting time problems, Teor. Veroyatn. $i$ Primenen. 2, (1957) 92-105.

[47] On a stochastic process concerning some waiting time problems, Theory of Probability and Appl. 2, (1957) 90-103.

[48] Bizonyos várakozási idö problémákról, Magyar Tud. Akadémia Mat. Fiz. Oszt. Közl. 7, (1957) 183-197.

[49] On some probability problems concerning the theory of counters, Acta Math. Acad. Sci. Hungaricae, 8, (1957) 127-138.

[50] On random walk problems. (Hungarian. Russian and English summaries.), Magyar Tud. Akadémia Mat. Kut. Int. Közl. 2, (1957) 81-90.

[51] On limiting distributions concerning a sojourn time problem, Acta Math. Acad. Sci. Hungaricae, 8, (1957) 279-294.

[52] On secondary stochastic processes generated by a multidimensional Poisson process, Magyar Tud. Akadémia Mat. Kut. Int. Közl. 2, (1957) 71-80.

[53] On a generalization of the renewal theory, Magyar Tud. Akadémia Mat. Kut. Int. Közl. 2, (1957) 91-103.

[54] Tartózkodási idö problémákrol, Magyar Tud. Akadémia Mat. Fiz. Oszt. Közl. 7, (1957) 371-395.

[55] On a probability problem concerning telephone traffic, Acta Math. Acad. Sci. Hungaricae, 8, (1957) 319-324.

[56] On a queueing problem concerning telephone traffic, Acta Math. Acad. Sci. Hungaricae, 8, (1957) 325-335.

[57] Remarks on random walk problems, Magyar Tud. Akadémia Mat. Kut. Int. Közl. 2, (1957) 175-182.

[58] (with Medgyessy, P.), Valószinüségszámitás. Tankönyvkiadó, Budapest, 1957. Second edition, 1966. Third edition, 1973.

[59] (with Dallos, A.), Elektroncsövek nagyfrekvenciás bemeneti ellenállása, Tavközlési Kutató Intézet Közleményei, 3, No. 1, (1958) 35-81.

[60] On a generial probability theorem and its applications in the theory of stochastic processes, Proc. Cambridge Phil. Soc. 54, (1958) 219-224.

[61] On a probability problem in the theory of counters, Annals of Math. Statistics, 29, (1958) 
1257-1263.

[62] On a sojourn time problem, Teor. Veroyatn. i Primenen. 3, (1958) 61-69.

[63] On a sojourn time problem, Theory of Probability and Appl. 3, (1958) 58-65.

[64] On a combined waiting time and loss problem concerning telephone traffic, Ann. Univ. Sci. Budapest. R. Eötvös. Sect. Math. 1, (1958) 73-82.

[65] On the probability distribution of the measure of the union of random sets placed in a Euclidean space, Ann. Univ. Sci. Budapest. R. Eötvös. Sect. Math. 1, (1958) 89-95.

[66] A telefon-forgalom elméletének néhány valószinüségszámitási kérdéséröl, Magyar Tud. Akadémia Mat. Fiz. Oszt. Közl. 8, (1958) 151-210.

[67] On a coincidence problem concerning telephone traffic, Acta Math. Acad. Sci. Hungaricae, 9, (1958) 45-81.

[68] Probabilistic treatment of meteoropathological phenomena. (Hungarian. Russian and English summaries.), Magyar Tud. Akadémia Mat. Kut. Int. Közl. 3, (1958) 129-140.

[69] On a sojourn time problem in the theory of stochastic processes, Trans. Amer. Math. Soc. 93, (1959) 531-540.

[70] On the limiting distribution of the number of coincidences concerning telephone traffic, Annals of Math. Statistics, 30, (1959) 134-142.

[71] Nekotorye veroyatnostnye zadchi v telefonya, Matematika, 4, No. 6, (1960) 93-144.

[72] Stochastic Processes. Problems and Solutions. Methuen and Co., London; John Wiley and Sons, New York, 1960. Reprinted: 1962, 1966, 1968. Science paperbacks: 1966, 1968.

[73] Transient behavior of single-server queuing processes with recurrent input and exponentially distributed service times, Operations Research, 8, (1960) 231-245.

[74] On a coincidence problem concerning particle counters, Annals of Math. Statistics, 32, (1961) 739-756.

[75] The transient behavior of a single-server queuing process with recurrent input and gamma service time, Annals of Math. Statistics, 32, (1961) 1286-1298.

[76] The time dependence of Palm's loss formula, Journ. Math. Anal. and Appl. 2, (1961) 5871.

[77] Transient behavior of single-server queueing processes with Erlang input, Trans. Amer. Math. Soc. 100, (1961) 1-28.

[78] The transient behavior of a single server queueing process with a Poison input, Proc. Fourth Berkeley Symp. Math. Stat. and Prob., Univ. of California Press, 2, (1961) 535567.

[79] The probability law of the busy period for two types of queuing processes, Operations Research, 9, (1961) 402-407.

[80] Charles Jordan, 1871-1959, Annals of Math. Statistics, 32, (1961) 1-11.

[81] Stochastic processes with balking in the theory of telephone traffic, Bell Systems Techn. Journ. 40, (1961) 795-820.

[82] Introduction to the Theory of Queues. Oxford University Press, New York, 1962. Reprinted by Greenwood Press, Westport, Conn., 1982.

[83] A generalization of the ballot problem and its application in the theory of queues, Journ. Amer. Stat. Assoc. 57, (1962) 327-337.

[84] Delay distributions for simple trunk groups with recurrent input and exponential service times, Bell System Techn. Journ. 41, (1962) 311-320.

[85] The time dependence of a single-server queue with Poisson input and general service times, Annals of Math. Statistics, 33, (1962) 1340-1348.

[86] A combinatorial method in the theory of queues, Journ. Soc. Ind. Appl. Math. 10, (1962) 691-694.

[87] A single-server queue with Poisson input, Operations Research, 10, (1962) 388-394.

[88] A single-server queue with recurrent input and exponentially distributed service times, Operations Research, 10, (1962) 395-399. 
[89] Ballot problems, Zeitschr. f. Wahrscheinlichkeitstheorie u. verw. Geb. 1, (1962) 154-158.

[90] Probability-theoretical determination of secondary electron emission, Selected Translations in Mathematical Statistics and Probability, IMS and AMS, Providence, R.I., 4, (1963) 133146.

[91] The stochastic law of the busy period for a single server queue with Poisson input, Journ. Math. Anal. and Appl. 6, (1963) 33-42.

[92] Delay distributions for one line with Poisson input, general holding times, and various orders of service, Bell System Techn. Journ. 42, (1963) 487-503.

[93] The limiting distribution of the virtual waiting time and the queue size for a single-server queue with recurrent input and general service times, Sankhyā., Ser. A, 25, (1963) 91-100.

[94] A single-server queue with feedback, Bell System Techn. Journ. 42, (1963) 505-519.

[95] The distribution of majority times in a ballot, Zeitschr. f. Wahrscheinlichkeitstheorie u. verw. Geb. 2, (1963) 118-121.

[96] The distribution of the virtual waiting time for a single-server queue with Poisson input and general service times, Operations Research, 11, (1963) 261-264.

[97] Combinatorial methods in the theory of queues, Review Inter. Stat. Inst. 32, (1964) 207219.

[98] A combinatorial method in the theory of Markov chains, Journ. Math. Anal. and Appl. 9, (1964) 153-161.

[99] Combinatorial methods in the theory of dams, Journ. Applied Probability, 1, (1964) 69-76.

[100] From ballot theorems to the theory of queues. Abstract: Post Office Telecommunications Journ. Special Issue. Report of the Proceedings of the Fourth International Teletraffic Congress, London, 1964, 25-26.

[101] Priority queues, Operations Research, 12, (1964) 63-74.

[102] Fluctuations in the ratio of scores in counting a ballot, Journ. Applied Probability, 1, (1964) 393-396.

[103] The use of a ballot theorem in order statistics, Journ. Applied Probability, 1, (1964) 389392.

[104] An application of a ballot theorem in order statistics, Annals of Math. Statistics, 35, (1964) 1356-1358.

[105] Occupation time problems in the theory of queues, Operations Research, 12, (1964) 753767.

[106] Processus Stochastiques. Problèmes et Solutions, Dunod, Paris, 1964.

[107] Applications of a ballot theorem in physics and in order statistics, Journ. Royal Statist. Society, Ser. B, 27, (1965) 130-137.

[108] On the distribution of the supremum for stochastic processes with interchangeable increments, Trans. Amer. Math. Society, 119, (1965) 367-379.

[109] Application of ballot theorems in the theory of queues, Proceedings of the Symposium on Congestion Theory, August 24-26, 1964. Edited by W. L. Smith and W. E. Wilkinson. University of North Carolina, Chapel Hill, N. C., 1965, 337-398.

[110] A moment problem, Journ. Australian Math. Society, 5, (1965) 487-490.

[111] The distribution of some statistics depending on the deviations between empirical and theoretical distribution functions, Sankhā. Ser. A 27 (1965) 93-100.

[112] A combinatorial theorem for stochastic processes, Bull. Amer. Math. Soc. 71, (1965) 649650 .

[113] The distribution of the content of a dam when the input process has stationary independent increments, Journ. Math. and Mech. 15, (1966) 101-112.

[114] Stochastische Prozesse. Aufgaben und Lösungen. R. Oldenbourg, München, 1966.

[115] On combinatorial methods in the theory of stochastic processes, Proc. Fifth Berkeley Symp. Math. Stat. and Prob., Univ. of California Press, 2, No. 1, (1967) 431-447.

[116] On the method of inclusion and exclusion, Journ. Amer. Stat. Assoc. 62, (1967) 102-113.

[117] The distribution of the content of finite dams, Journ. Applied Probability, 4, (1967) 151- 
161.

[118] Combinatorial Methods in the Theory of Stochastic Processes. John Wiley and Sons, New York, 1967. Reprinted by R. E. Krieger, Huntington, New York, 1977.

[119] On dams of finite capacity, Journ. Australian Math. Society, 8, (1968) 161-170.

[120] Two queues attended by a single server, Operations Research, 16, (1968) 639-650.

[121] On Erlang's formula, Annals of Math. Statistics, 40, (1969) 71-78.

[122] On inverse queueing processes, Zastosowania Matematyki (Applicationes Mathematicae), 10, (1969) 213-224.

[123] On the classical ruin problems, Journ. Amer. Stat. Assoc. 64, (1969) 889-906.

[124] On the fluctuations of election returns, Journ. Applied Probability, 7, (1970) 114-123.

[125] On the distribution of the supremum for stochastic processes, Annales de l'Institut Henri Poincaré. Section B. Calcul des Probabiltés et Statistique, 6, (1970) 237-247.

[126] Combinatorial methods in the theory of order statistics, Nonparametric Techniques in Statistical Inference. Edited by M. L. Puri. Cambridge University Press, 1970, 359-384.

[127] On the distribution of the maximum of sums of mutually independent and identically distributed random variables, Advances in Applied Probability, 2, (1970) 344-354.

[128] A fundamental indentity in the theory of queues, Annals of the Institute of Statistical Mathematics, 22, (1970) 339-348.

[129] On risk reserve processes, Skandinavisk Aktuarietidskrift, 53, (1970) 64-75.

[130] Kombinatornye Metody v Teorii Sluchainyh Processov. Izdat. "MIR", Moskva, 1971.

[131] On the comparison of a theoretical and an empirical distribution function, Journ. Applied Probability, 8, (1971) 321-330.

[132] On the comparison of two empirical distribution functions, Annals of Math. Statistics, 42, (1971) 1157-1166.

[133] The distribution of the occupation time for single-server queues, Operations Research, 19, (1971) 1494-1501.

[134] Discrete queues with one server, Journ. Applied Probability, 8, (1971) 691-707.

[135] On a formula of Pollaczek and Spitzer, Studia Mathematica, 41, (1972) 27-34.

[136] On a linear transformation in the theory of probability, Acta Sci. Math. (Szeged), 33, (1972) 15-24.

[137] On a method of Pollaczek, Stochastic Processes and their Applications, 1, (1973) 1-9.

[138] On an indentity of Shih-Chieh Chu, Acta Sci. Math. (Szeged), 34, (1973) 383-391.

[139] Sojourn time problems, Annals of Probability, 2, (1974) 420-431.

[140] Occupation time problems in the theory of queues. Proceedings of the Conference on Mathematical Methods in Queueing Theory. Western Michigan University, May 10-12, 1973. Lecture Notes In Economics and Mathematical Systems. Vol. 98. Springer-Verlag, New York, 1974, 91-131.

[141] A single server queue with limited virtual waiting time, Journ. Applied Probability, 11, (1974) 612-617.

[142] On a formula of Harald Cramér, Scandinavian Actuarial Journal, 2, (1975) 65-72.

[143] Combinatorial and analytic methods in the theory of queues, Advances in Applied Probability, 7, (1975) 607-635.

[144] A storage process with semi-Markov input, Advances in Applied Probability, 7, (1975) 830844.

[145] On a problem of fluctuations of sums of independent random variables. Perspectives in Probability and Statistics. Papers in honour of M. S. Bartlett. Edited by J. Gani. Academic Press, London, 1975, 29-37.

[146] On the maximal deviation between two empirical distribution functions, Studia Sci. Math. Hungarica, 10, (1975) 117-121.

[147] On the busy periods of single-server queues with Poisson input and general service times, Operations Research, 24, (1976) 564-571.

[148] Some remarks on a counter process, Journ. Applied Probability, 13, (1976) 623-627. 
[149] On fluctuation problems in the theory of queues, Advances in Applied Probability, 8, (1976) 548-583.

[150] On some recurrence equations in a Banach algebra, Acta Sci. Math. (Szeged), 38, (1976) 399-416.

[151] A Banach space of matrix functions and its application in the theory of queues, Sankhyā, Ser. A, 38, (1976) 201-211.

[152] On the ordered partial sums of real random variables, Journ. Applied Probability, 14, (1977) 75-88.

[153] An identity for ordered partial sums, Journ. Combinatorial Theory, Ser. A, 23, (1977) 364365 .

[154] A queueing model with feedback, R.A.I.R.O. Série: Recherche Opérationelle, 11, (1977) 345-354.

[155] Queueing processes, Mathematical Spectrum, 10, (1977-1978) 82-88. [Reprinted: ORSA and TIMS. Applied Probability Newsletter, 8, No. 2, (1984) 2-4.]

[156] An increasing continuous singular function, American Math. Monthly, 85, (1978) 35-37.

[157] On fluctuations of sums of random variables. Studies in Probability and Ergodic Theory. Advances in Mathematics. Supplementary Studies. Vol. 2. Edited by G.-C. Rota. Academic Press, New York, 1978, 45-93.

[158] A sum of binomial coefficients, Mathematics of Computation, 32, (1978) 1271-1273.

[159] Fluctuation problems for Bernoulli trials, SIAM Review, 21, (1979) 222-228.

[160] On generalized Dedekind sums, Journ. Number Theory, 11, (1979) 264-272.

[161] On an urn problem of Paul and Tatiana Ehrenfest, Math. Proc. Cambridge Phil. Soc. 86, (1979) 127-130.

[162] (with Letac, G.), Random walks on a m-dimensional cube, Journ. f. reine u. angewandte Math. 310, (1979) 187-195.

[163] A generalization of the Eulerian numbers, Publicationes Mathematicae (Debrecen), 26, (1979) 173-181.

[164] The problem of coincidences, Archive for History of Exact Sciences, 21, (1980) 229-244.

[165] On a theorem of Gy. Hajós, Periodica Mathematica Hungarica, 11, (1980) 159-160.

[166] (with Letac, G.), Random walks on a 600-cell, SIAM Journ. Algebraic and Discrete Methods, 1, (1980) 114-120.

[167] Queues with infinitely many servers, R.A.I.R.O. Operations Research, 14, (1980) 109-113.

[168] (with Letac, G.), Random walks on a dodecahedron, Journ. Applied Probability, 17, (1980) $373-384$.

[169] The arc sine law of Paul Lévy, Contributions to Probability, A Collection of Papers Dedicated to Eugene Lukács. Edited by J. Gani and V. K. Rohatgi. Academic Press, New York, 1981, 49-63.

[170] On a combinatorial theorem related to a theorem of G. Szegö, Journ. Combinatorial Theory, Ser. A, 30, (1981) 345-348.

[171] Random flights on regular polytopes, SIAM Journ. on Algebraic and Discrete Methods, 2, (1981) 153-171.

[172] On the "problème des ménages", Discrete Mathematics, 36, (1981) 289-297.

[173] Random walks on groups, Linear Algebra and its Applications, 43, (1982) 49-67.

[174] Ballot problems. Encyclopedia of Statistical Sciences. Vol. 1. Edited by S. Kotz and N. L. Johnson. John Wiley and Sons, New York, 1982, 183-188.

[175] Combinatorics, Encyclopedia of Statistical Sciences. Vol. 2. Edited by S. Kotz and N. L. Johnson. John Wiley and Sons, New York, 1982, 53-59.

[176] Random walk on a finite group, Acta Sci. Math. (Szeged), 45, (1983) 395-408.

[177] Combinatorics. Handbook of Statistics. Vol. 4. Nonparametric Methods. Edited by P. R. Krishnaiah and P. K. Sen. North-Holland Publishing Co., Amsterdam, 1984, 123-143.

[178] Random flights on regular graphs, Advances in Applied Probability, 16, (1984) 618-637.

[179] On a problem of Gy. Hajós, Periodica Mathematica Hungarica, 15, (1984) 315-316. 
[180] Harmonic analysis on Schur Algebras and its applications in the theory of probability. Probability Theory and Harmonic Analysis. Edited by J.-A. Chao and W. A. Woyczyński. Marcel Dekker, Inc., New York, 1986, 227-283.

[181] Reflection principle. Encyclopedia of Statistical Sciences. Vol. 7. Edited by S. Kotz and N. L. Johnson. John Wiley and Sons, New York, 1986, 670-673.

[182] Some asymptotic formulas for lattice paths, Journ. Statistical Planning and Inference, 14, (1986) 123-142.

[183] Chance or determinism? The Craft of Probabilistic Modelling. A Collection of Personal Accounts. Edited by J. Gani. Springer-Verlag, New York, 1986, 139-149.

[184] Takács process. Encyclopedia of Statistical Sciences. Vol. 9. Edited by S. Kotz and N. L. Johnson. John Wiley and Sons, New York, 1988, 177-179.

[185] On the limit distribution of the number of cycles in a random graph, A Celebration of Applied Probability. Edited by J. Gani. Journ. Applied Probability. Special Volume, 25A, (1988) 359-376.

[186] Queues, random graphs and branching processes, Journal of Applied Mathematics and Simulation, 1, (1988) 223-243.

[187] Book Review: Random Mappings by Valentin F. Kolchin, Bull. Amer. Math. Soc. 19, (1988) 511-515.

[188] Ballots, queues and random graphs, Journ. Applied Probability, 26, (1989) 103-112.

[189] On Cayley's formula for counting forests, Journ. Combinatorial Theory, Ser. A, 53, (1990) 321-323.

[190] A generalization of an inequality of Stepanov, Journ. Combinatorial Theory, Ser. B, 48, (1990) 289-293.

[191] Counting Forests, Discrete Mathematics, 84, (1990) 323-326.

[192] On the number of distinct forests, SIAM Journ. Discrete Mathematics, 3, (1990) 574-581.

[193] A moment convergence theorem, Amer. Math. Monthly, 98, (1991) 742-746.

[194] A Bernoulli excursion and its various applications, Advances in Appl. Probability, 23, (1991) 557-585.

[195] On a probability problem connected with railway traffic, Journal of Applied Mathematics and Stochastic Analysis, 4, (1991) 1-27.

[196] On the distribution of the number of vertices in layers of random trees, Journal of Applied Mathematics and Stochastic Analysis, 4, (1991) 175-186.

[197] Conditional limit theorems for branching processes, Journal of Applied Mathematics and Stochastic Analysis, 4, (1991) 263-292.

[198] Random walk processes and their applications in order statistics, Annals of Applied Probability, 2, (1992) 435-459.

[199] Limit theorems for random trees, Proc. Nat. Acad. Sci. USA, 89, (1992) 5011-5014.

[200] On the total heights of random rooted trees, Journ. Applied Probability, 29, (1992) 543556.

[201] Random walk processes and their various applications, Probability Theory and Applications. Essays to the Memory of József Mogyoródi, edited by J. Galambos and I. Kátai. Kluwer, Dordrecht, 1992, 1-32.

[202] On the distribution of the integral of the absolute value of the Brownian motion, Annals of Applied Probability, 3, (1993) 186-197.

[203] Enumeration of rooted trees and forests, The Mathematical Scientist, 18, (1993) 1-10.

[204] The asymptotic distribution of the total heights of random rooted trees, Acta Scientiarum Mathematicarum (Szeged), 57, (1993) 613-625.

[205] Pollaczek's results in fluctuation theory, Archiv für Elektronik und Übertragungstechnik, 47, (1993) 322-325.

[206] Limit distributions for queues and random rooted trees, Journal of Applied Mathematics and Stochastic Analysis, 6, (1993) 189-216.

[207] On the total heights of random rooted binary trees, Journal of Combinatorial Theory, Ser. 
B, 61, (1994) 155-166.

[208] Theory of Probability, Encyclopedia of Applied Physics, Vol. 1, edited by G. L. Trigg, VCH Publishers, Weinheim and New York, 1994, to appear.

[209] The problem of points, The Mathematical Scientist, 19, (1994) 119-139.

[210] Limit distributions for the Bernoulli meander, Journal of Applied Probability, 32, (1995) to appear.

[211] Queueing methods in the theory of random graphs, Frontiers in Queueing: Theory and Methods, Edited by J. H. Dshalalow, CRC Press, Boca Raton, Florida, 1995, to appear. 


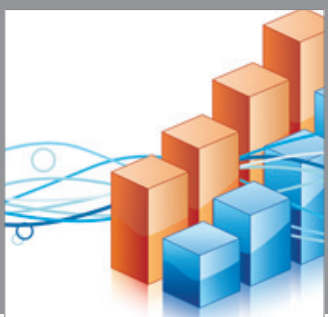

Advances in

Operations Research

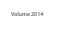

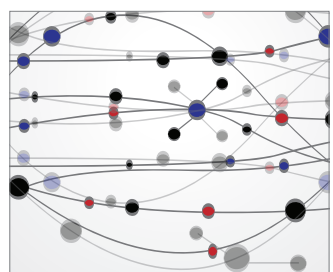

\section{The Scientific} World Journal
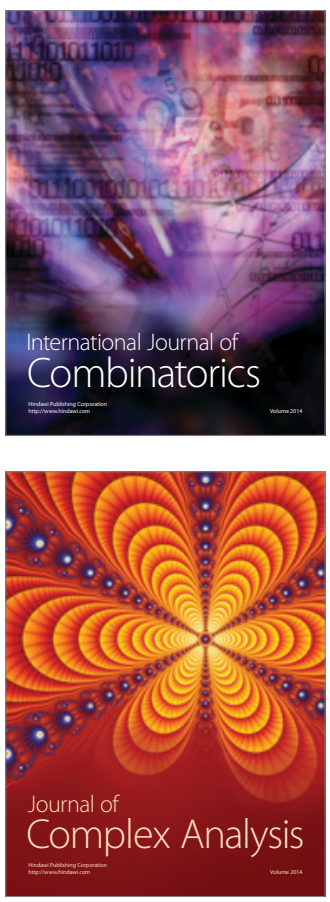

International Journal of

Mathematics and

Mathematical

Sciences
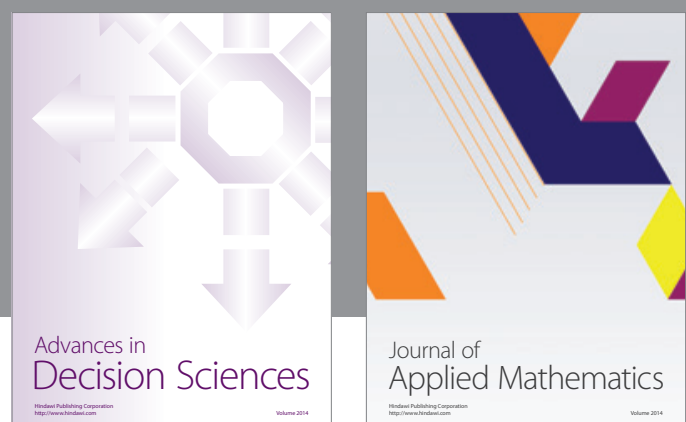

Journal of

Applied Mathematics
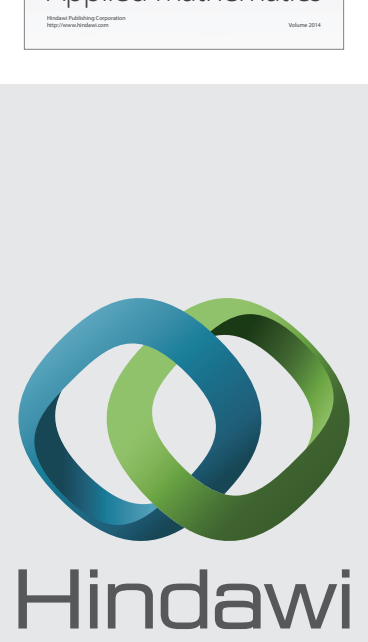

Submit your manuscripts at http://www.hindawi.com
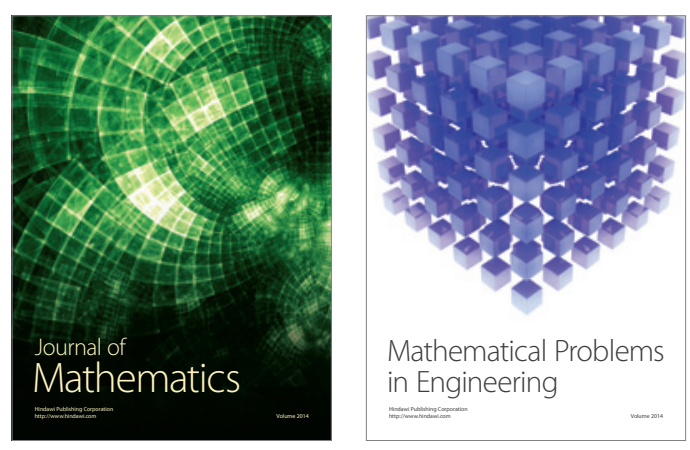

Mathematical Problems in Engineering
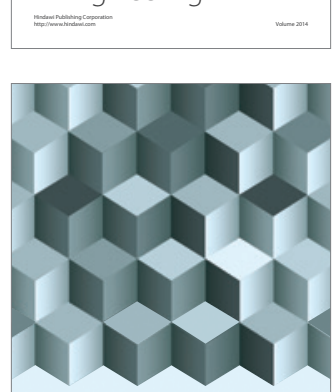

Journal of

Function Spaces
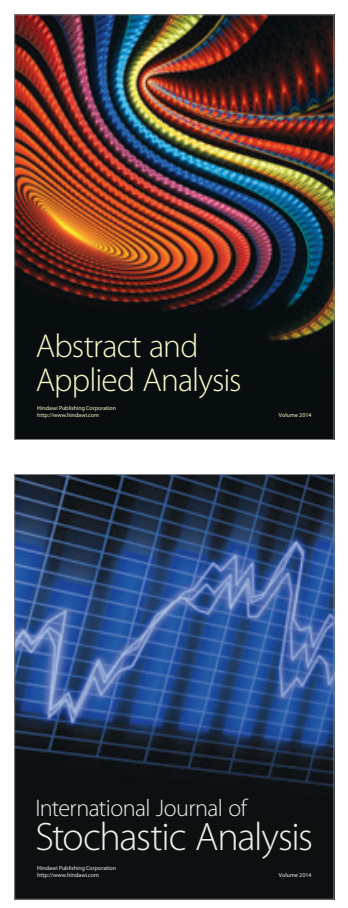

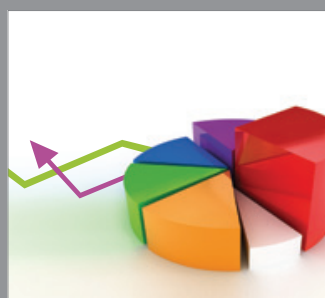

ournal of

Probability and Statistics

Promensencen
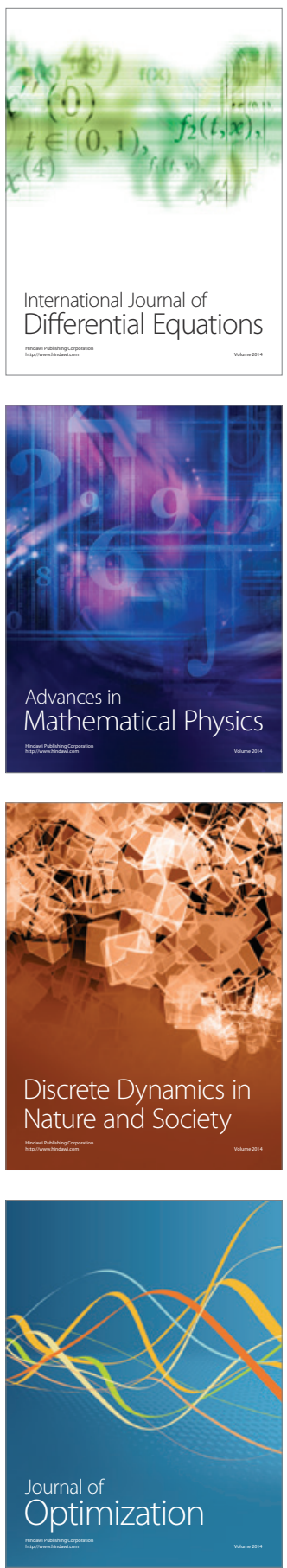